\title{
Impact of dietary protein on lipid metabolism- related gene expression in porcine adipose tissue
}

\author{
Sumei Zhao ${ }^{\dagger}$, Jing Wang ${ }^{\dagger}$, Xinlei Song, Xi Zhang, Changrong Ge, Shizheng Gao*
}

\begin{abstract}
Background: High dietary protein can reduce fat deposition in animal subcutaneous adipose tissue, but little is known about the mechanism.

Methods: Sixty Wujin pigs of about $15 \mathrm{~kg}$ weight were fed either high protein (HP: 18\%) or low protein (LP: 14\%) diets, and slaughtered at body weights of 30,60 or $100 \mathrm{~kg}$. Bloods were collected to measure serum parameters. Subcutaneous adipose tissues were sampled for determination of adipocyte size, protein content, lipid metabolismrelated gene expression, and enzyme activities.

Results: HP significantly reduced adipocyte size, fat meat percentage and backfat thickness, but significantly increased daily gain, lean meat percentage and loin eye area at 60 and $100 \mathrm{~kg}$. Serum free fatty acid and triglyceride concentrations in the HP group were significantly higher than in the LP group. Serum glucose and insulin concentrations were not significantly affected by dietary protein at any body weight. HP significantly reduced gene expression of acetyl CoA carboxylase (ACC), fatty acid synthase (FAS) and sterol regulatory element binding protein 1c (SREBP-1c) at $60 \mathrm{~kg}$ and $100 \mathrm{~kg}$; however, the mRNA level and enzyme activity of FAS were increased at $30 \mathrm{~kg}$. HP promoted gene and protein expression and enzyme activities of lipoprotein lipase (LPL), carmitine palmtoyltransferase-1B (CPT-1B), peroxisome proliferator-activated receptor $\gamma$ (PPAR $\gamma$ ) and adipocyte-fatty acid binding proteins (A-FABP) at $60 \mathrm{~kg}$, but reduced their expression at $100 \mathrm{~kg}$.

Gene expression and enzyme activity of hormone sensitive lipase (HSL) was reduced markedly at $60 \mathrm{~kg}$ but increased at $100 \mathrm{~kg}$ by the high dietary protein. Levels of mRNA, enzyme activities and protein expression of ACC, FAS, SREBP-1C and PPAR $\gamma$ in both LP and HP groups increased with increasing body weight. However, gene and protein expression levels/enzyme activities of LPL, CPT-1B, A-FABP and HSL in both groups were higher at $60 \mathrm{~kg}$ than at 30 and $100 \mathrm{~kg}$.

Conclusion: Fat deposition in Wujin pigs fed high dietary protein for 25 weeks was reduced mainly by depression of lipogenic gene expression. The mechanism of lipid transport, lipolysis and oxidation in adipose tissue regulated by dietary protein appeared to be different at $60 \mathrm{~kg}$ and $100 \mathrm{~kg}$ body weights.
\end{abstract}

\section{Background}

The deposition of fat in meat animals may be beneficial or undesirable depending on its quantity and location. Excessive deposition of fat, except intramuscular fat, has been recognized as detrimental to carcass quality, and constitutes a health risk to human consumers [1]. The synthesis of subcutaneous adipose tissue triglycerides the major constituents of depot fat - either proceeds from fatty acids synthesized de novo in that tissue $[2,3]$

\footnotetext{
* Correspondence: gaoszkm@126.com

+ Contributed equally

Yunnan Key Laboratory of Animal Nutrition and Feed Science, Yunnan Agricultural University, Kunming 650201, China
}

or from fatty acids obtained from circulating triglycerides as a result of adipose tissue lipoprotein lipase activity [4]. This suggests that the relative rates between synthesis and degradation of fatty acids determining deposition or utilization of depot fat in subcutaneous adipose tissue may be indicative of total body fat in animals and obesity in humans.

Processes that determine fat deposition in adipose tissue include the rates of fat uptake, de novo fatty acid synthesis, triacylglycerol synthesis, lipid degradation and transport processes of fatty acids [5]. Several key factors are involved in lipid metabolism in adipose tissues. Lipogenic enzymes include acetyl-CoA carboxylase 
(ACC), fatty acid synthase (FAS), malic enzyme (ME) and glucose-6-phosphate dehydrogenase (G-6-PDH), and changes in their activities can alter the rates of biosynthesis of fatty acids [6-11]. Moreover, hormone-sensitive lipase (HSL) and carnitine palmitoyltransferase 1 (CPT-1) are rate limiting enzymes in catabolism, responsible for hydrolysis of triglycerides and importing esters of fatty acids to mitochondria for $\beta$-oxidation $[12,13]$. Lipoprotein lipase (LPL) is the rate limiting enzyme for the conversion of chylomicrons and VLDL into chylomicron remnants and LDL. LPL is regarded as rate limiting for the transfer of fatty acids into tissues [12]. Furthermore, sterol regulatory element binding protein 1(SREBP-1), peroxisome proliferator-activated receptor $\gamma(\operatorname{PPAR} \gamma)$ and adipose fatty acids-binding protein (A-FABP, also known as FABP4), have recently been identified as being implicated in lipid metabolism in adipose tissue by regulating gene expression of enzymes or proteins involved in lipid metabolism, or by transporting fatty acids [14-18].

The Wujin pig is a typical local breed in Yunnan province, China. Compared with other breeds, the Wujin pig has higher body fat, especially of intramuscular fat [19]. Because of the similarity of adipose tissue lipid metabolism in pigs and humans, the fatty pig is an ideal model for investigation of lipid metabolism in human adipose tissue $[20,21]$.

Previous reports have revealed that high dietary protein can reduce carcass fat contents of pigs [22-26]. Litthe is known about the regulatory mechanisms of dietary protein on porcine adipose tissue lipid metabolism, and of the effect of dietary protein levels on gene expression relating to lipid metabolism. This study attempts to clarify some aspects of these, using Wujin pigs as an experimental model.

\section{Methods}

All experimental procedures were approved by the Yunnan Agricultural University Committee of Laboratory Animal Care.

\section{Experimental diets}

Dietary protein was formulated at two levels: low (14\%, LP) and high (18\%, HP), these being $2 \%$ below and above the Chinese feeding standard for local breed pigs [27]. Digestive energy of two groups was kept the same $(13.56 \mathrm{MJ} / \mathrm{kg})$. Composition and calculated nutrient contents of the experimental diets are presented in table 1.

\section{Pigs and housing}

Two males and two females, weight approximately 15 $\mathrm{kg}$, were selected from each of 15 litters. One male and one female constituted a unit, giving a total of 30 units, which were randomly divided into two main groups according to their diet (LP or HP). The pigs were individually housed in an insulated but unheated shed with a
Table 1 Composition of diets (\%, as fed basis)

\begin{tabular}{lll}
\hline & LP $^{\mathbf{1}}$ & HP $^{\mathbf{2}}$ \\
\hline Corn & 73.72 & 60.46 \\
Wheat bran & 10.00 & 15.00 \\
Soybean meal & 8.38 & 16.14 \\
Fish meal & 4.50 & 5.00 \\
Soybean oil & 1.00 & 1.00 \\
Monocalcium phosphate & 0.20 & 0.20 \\
Limestone & 0.90 & 0.90 \\
Salt & 0.30 & 0.30 \\
Premix & \\
Calculated nutritional composition & 4 & 1.00 \\
Crude protein & 1.00 & \\
Total lysine & 14.00 & 18.00 \\
Digestive energy & 0.96 & 0.96 \\
(MJ/kg) & 13.56 & 13.56 \\
Calcium & & \\
Total phosphorus & 0.64 & 0.64 \\
Available phosphorus & 0.55 & 0.55 \\
\hline
\end{tabular}

${ }^{1}$ LP: low protein diet.

${ }^{2}$ HP: high protein diet

${ }^{3}$ Vitamin premix provided the following per kilogram of diet: vitamin A, 8,267 $\mathrm{IU}$; vitamin D2, 2,480 IU; vitamin E, $66 \mathrm{IU}$; menadionine [as menadionine pyrimidinol bisulfite complex], $6.2 \mathrm{mg}$; riboflavin, $10 \mathrm{mg}$; Ca d-pantothenic acid, 37 mg; niacin, 66 mg; vitamin B12, $45 \mu$; d-biotin, $331 \mu$; folic acid, 2.5 $\mathrm{mg}$; pyridoxine, $3.31 \mathrm{mg}$; thiamine, $3.31 \mathrm{mg}$; vitamin C, $83 \mu \mathrm{g}$; Trace mineral premix provided the following per kilogram of diet: Zn, $127 \mathrm{mg} ; \mathrm{Fe}, 127 \mathrm{mg}$; $\mathrm{Mn}, 20 \mathrm{mg}$; Cu, $12.7 \mathrm{mg}$; $10.80 \mathrm{mg}$, as zinc sulfate, ferrous sulfate, manganese sulfate, copper sulfate, ethylenediamine dihydriodide, respectively, with calcium carbonate as the carrier, providing $0.3 \mathrm{mg}$ Se per kilogram of diet.

${ }^{4}$ Nutritional compositions were calculated values based on China Feed Database.

half slatted floor at the research station of Yunnan Agricultural University (March to October). They were given free access to water from nipple drinkers and their diets were provided ad libitum. They were weighed individually for calculation of average daily gain.

At body weights of $30 \mathrm{~kg}$ (end of the grower period), $60 \mathrm{~kg}$ (end of the early-finishing period) and $100 \mathrm{~kg}$ (end of the late-finishing period), groups of pigs were transported to the Yunnan Agricultural Center Meats Laboratory, and were slaughtered by exsanguination after electrical stunning. Blood samples were collected. Sera were separated by low speed centrifugation and stored at $-20^{\circ} \mathrm{C}$ until required. Subcutaneous adipose tissue samples were taken from between the second and fourth thoracic vertebrae, snap frozen in liquid nitrogen, and stored at $-80^{\circ} \mathrm{C}$ prior to analysis.

\section{Determination of adipocyte size}

Adipocytes were obtained by collagenase treatment of fresh tissue from each sample. Adipocyte size was determined according to the method of Etherton and Chung [28]. Briefly, aliquots $\left(10^{3}\right.$ cells $)$ of isolated adipocytes were digitally photographed using a photomicroscopy system, and individual diameters $(\mu \mathrm{m})$ were measured 
using an image analysis system (Optimas 6.5; Media Cybernetics, Silver Spring, MD).

\section{Serum analysis}

Serum free fatty acids (FFA), triglycerides (TG) were determined with commercial kits (Nanjing Jiancheng Biochemical Reagent Co., Nanjing, China).

Serum insulin concentrations were measured with a commercial multi-species RIA kit (Beijing North Institute of Biotechnology) that had been validated for measuring porcine serum samples. Detection limits for insulin were $0.2 \mathrm{ng} / \mathrm{mL}(1.0 \mu \mathrm{IU} / \mathrm{mL})$ with intra- and inter-assay coefficients of variation of $5 \%$ and $10 \%$, respectively.

\section{Adipose tissue enzyme activity analyses}

The activities of acetyl-CoA carboxylase (ACC, EC 6.4.1.2), fatty acid synthase (FAS, EC 2.3.1.85), malic enzyme (ME, EC 1.1.1.40), glucose-6-phosphate dehydrogenase (G-6-PDH, EC 1.1.1.49), hormone-sensitive lipase (HSL, EC 3.1.1.3) and lipoprotein lipase (LPL, EC 3.1.1.34) were determined in subcutaneous adipose tissue homogenates. Approximately $1 \mathrm{~g}$ adipose tissue was homogenized in $3 \mathrm{~mL} 10 \mathrm{mM}$ HEPES buffer containing $0.25 \mathrm{M}$ sucrose, $1 \mathrm{mM}$ EDTA, and $1 \mathrm{mM}$ dithiothreitol, and then centrifuged at $100,000 \mathrm{~g}$ for $30 \mathrm{~min}$ at $4^{\circ} \mathrm{C}$. Supernatants were collected and used for the enzyme assays. The activity of ACC was assayed by the $\mathrm{H}^{14} \mathrm{CO}_{3}$ fixation method [29,30]. Spectrophotometric assays were used for ME [31], G-6-PDH [32], and FAS [33,34]. LPL activity was determined using a commercial kit (Nanjing Jiancheng Biochemical Reagent Co) according to the manufacturer's instructions. The assay for HSL activity was based on a cholesterol esterase assay described by Osterlund et al. [35]. The CPT-1 activity was assayed directly using whole mitochondrial isolates which were resuspended at $0^{\circ} \mathrm{C}$ in $0.3 \mathrm{M}$ sucrose containing $10 \mathrm{mM}$ Tris- $\mathrm{HCl}, \mathrm{pH} 7.4$, and $1 \mathrm{mM}$ EGTA, sonicated, then centrifuged at $20,000 \mathrm{~g}$ for $40 \mathrm{~min}$ at $4^{\circ} \mathrm{C}$ to obtain a mitochondrial supernatant [36]. All assays were conducted in the range of linearity with respect to amount of enzyme and time. Soluble protein in the tissue supernatants was measured according to the method of Bradford [37], using bovine serum albumin as the standard. Unless otherwise noted, all reagents were obtained from Sigma (USA).

\section{RNA extraction}

Total RNA was extracted from subcutaneous adipose tissue using TRIZOL reagent (Invitrogen, USA) according to the manufacturer's protocol, and quantified by measurement of optical density at $260 \mathrm{~nm}$. Ratios of absorption (260/280 $\mathrm{nm})$ of all preparations were between 1.6 and 1.8. Aliquots of RNA samples were subjected to electrophoresis in a $1 \%$ ethidium bromidestained $1.4 \%$ agarose formaldehyde gel to verify their integrity.

\section{Real-Time quantitative RT-PCR}

Reverse transcription was performed using the RNA $(2 \mu \mathrm{g})$ in a final volume of $25 \mu \mathrm{L}$ containing 10 units MMLV reverse transcriptase (Promega, USA), $1 \mathrm{mM}$ dNTP mixture (Promega, USA), 40 units recombinant RNasin ribonuclease inhibitor (Promega, USA) and 0.5 $\mu \mathrm{g}$ oligo (dT) 18 (Promega, USA) in sterile water and buffer supplied by the manufacturer. An aliquot of cDNA samples was mixed with $10 \mu \mathrm{L} \mathrm{iQ}^{\mathrm{m}} \mathrm{SYBR}^{\odot}$ Green Supermix (Takala, Japan), in the presence of $0.5 \mu \mathrm{M}$ of each forward and reverse primer for porcine ACC, FAS, SREBP-1, LPL, HSL, CPT-1, and PPAR $\gamma$, A-FABP, then subjected to PCR under standard conditions (40 cycles). The specific primers used for real-time quantitative PCR are listed in table 2. As an internal control, the same reverse transcription products were also subjected to PCR in the presence of a second pair of primers specific to pig $18 \mathrm{~S}$ rRNA. Mixtures were incubated in an iCyler

\begin{tabular}{|c|c|c|c|c|}
\hline $\begin{array}{l}\text { Gene } \\
\text { name }\end{array}$ & Sequence & $\mathrm{Ta}$ & $\begin{array}{l}\text { Product } \\
\text { size (bp) }\end{array}$ & $\begin{array}{l}\text { Genbank } \\
\text { accession no. }\end{array}$ \\
\hline $\begin{array}{l}18 S \\
\text { rRNA }\end{array}$ & $\begin{array}{l}\text { F: 5'- } \\
\text { GCGGCITTGGTGACTCTA- } \\
3^{\prime} \\
\text { R:5'- } \\
\text { CTGCCTCCTTGGATGTG-3' }\end{array}$ & $\begin{array}{l}60^{\circ} \\
\mathrm{C}\end{array}$ & $\begin{array}{l}194 \\
{[238-431]}\end{array}$ & NR_002170.3 \\
\hline $\mathrm{ACC}$ & $\begin{array}{l}\text { F: 5'-ATG TाT CGG CAG } \\
\text { TCC CTG AT-3' } \\
\text { R: 5'-TGT GGA CCA GCT } \\
\text { GAC CTT GA-3' }\end{array}$ & $\begin{array}{l}60^{\circ} \\
C\end{array}$ & $\begin{array}{l}133 \\
{[4810-} \\
4942]\end{array}$ & EF618729 \\
\hline FAS & $\begin{array}{l}\text { F: 5'-AGC CTA ACT CCT } \\
\text { CGC TGC AAT-3' } \\
\text { R: 5'-TCC TTG GAA CCG } \\
\text { TCT GTG TTC-3' }\end{array}$ & $\begin{array}{l}58^{\circ} \\
\mathrm{C}\end{array}$ & $\begin{array}{l}196 \mathrm{bp} \\
\text { [504-699] }\end{array}$ & AY183428 \\
\hline SREBP-1 & $\begin{array}{l}\text { F: 5'-GCG ACG GTG CCT } \\
\text { CTG GTA GT-3' } \\
\text { R: 5'-CGC AAG ACG GCG } \\
\text { GAT TTA-3' }\end{array}$ & $\begin{array}{l}62^{\circ} \\
\mathrm{C}\end{array}$ & $\begin{array}{l}218 \mathrm{bp} \\
{[194-411]}\end{array}$ & AF102873 \\
\hline$L P L$ & $\begin{array}{l}\text { F: 5'-AAC TTG TGG CTG } \\
\text { CCC TAT-3' } \\
\text { R: 5'-GAC CCT CTG GTG } \\
\text { AAT GTG-3' }\end{array}$ & $\begin{array}{l}55^{\circ} \\
\mathrm{C}\end{array}$ & $\begin{array}{l}367 \mathrm{bp} \\
{[453-819]}\end{array}$ & X62984 \\
\hline HSL & $\begin{array}{l}\text { F: 5'-GCT CCC ATC GTC } \\
\text { AAG AAT C-3' } \\
\text { R: 5'-TAA AGC GAA TGC } \\
\text { GGT CC-3' }\end{array}$ & $\begin{array}{l}55^{\circ} \\
\mathrm{C}\end{array}$ & $\begin{array}{l}262 \mathrm{bp} \\
{[2407-} \\
2668]\end{array}$ & AJ000482 \\
\hline PPAR- $\gamma$ & $\begin{array}{l}\text { F: 5'-GAT TTC TCC AGC } \\
\text { ATT TCC A-3' } \\
\text { R: 5'-GCT CTT CGT GAG } \\
\text { GTT TGT T-3' }\end{array}$ & $\begin{array}{l}60^{\circ} \\
\mathrm{C}\end{array}$ & $\begin{array}{l}184 \mathrm{bp} \\
{[270-453]}\end{array}$ & DQ437884 \\
\hline СРТ-1 & $\begin{array}{l}\text { F: 5'-ATG GTG GGC GAC } \\
\text { TAA CT-3' } \\
\text { R: 5'-TGC CTG CTG TCT } \\
\text { GTG AG-3' }\end{array}$ & $\begin{array}{l}62^{\circ} \\
\mathrm{C}\end{array}$ & $\begin{array}{l}321 \mathrm{bp} \\
{[681-1001]}\end{array}$ & AY181062 \\
\hline A-FABP & $\begin{array}{l}\text { F: 5'-CAG GAA AGT CAA } \\
\text { GAG CAC CA-3' } \\
\text { R: 5'-TCG GGA CAA TAC } \\
\text { ATC CAA CA-3' }\end{array}$ & $\begin{array}{l}55^{\circ} \\
\mathrm{C}\end{array}$ & $\begin{array}{l}227 \mathrm{bp} \\
{[234-460]}\end{array}$ & AJ416020 \\
\hline
\end{tabular}

\footnotetext{
${ }^{1}$ All porcine gene sequences.
} 
iQ Real-time Detection System (Bio-Rad, USA) programmed to perform in $25 \mu \mathrm{L}$ of total reaction volume as per manufacturer's instructions. PCR conditions consisted of an initial denaturation step at $94^{\circ} \mathrm{C}$ for $4 \mathrm{~min}$, then 40 cycles of denaturation/primer annealing/elongation $\left(94^{\circ} \mathrm{C}\right.$ for $50 \mathrm{~s} / 62^{\circ} \mathrm{C}$ for $1 \mathrm{~min} / 72^{\circ} \mathrm{C}$ for $1 \mathrm{~min}$, respectively) with a final extension at $72^{\circ} \mathrm{C}$ for $10 \mathrm{~min}$.

Melting curve analyses were performed on all real time PCR reactions to confirm specificity and identity of the real time PCR products. Specificity was further confirmed by agarose gel electrophoresis. To confirm the absence of significant contamination in the total RNA preparation, cDNA was synthesized and control reactions were performed in the absence of reverse transcriptase. In all cases, no further PCR bands were detected.

The results (fold changes) were expressed as $2^{-\Delta \Delta C t}$ with $\Delta \Delta \mathrm{Ct}=(\mathrm{Ct}$ ij-Ct $\beta$-18S rRNA j)-(Ct il-Ct $\beta$-18S rRNA l), where $\mathrm{Ct} i \mathrm{j}$ and $\mathrm{Ct} 18 \mathrm{~S}$ rRNA $\mathrm{j}$ are the $\mathrm{Ct}$ for gene $\mathrm{i}$ and for $18 \mathrm{~S}$ rRNA in a pool or a sample (named $\mathrm{j}$ ) and where $\mathrm{Ct}$ i1 and Ct $18 \mathrm{~S}$ rRNA 1 are the $\mathrm{Ct}$ in pool 1 or sample l, expressed as the standard. All primers used were designed by Primes Premier 5 and synthesized by Shanghai Shanggong Biological Company (Shanghai, China).

\section{Western blotting}

Whole frozen adipose samples $(0.5 \mathrm{~g})$ were homogenized on ice in $700 \mu \mathrm{L}$ buffer A [50 mM Tris- $\mathrm{HCl}(\mathrm{pH}$ 7.5), $50 \mathrm{mM} \mathrm{NaF}, 5 \mathrm{mM}$ sodium pyrophosphate, $1 \mathrm{mM}$ EDTA, $1 \mathrm{mM}$ DTT, $0.1 \mathrm{mM}$ phenylmethylsulfonyl fluoride, $10 \%$ glycerol] containing $1 \%$ Triton X-100, $5 \mu \mathrm{M}$ aprotinin, leupeptin and pepstatin. The lysates were centrifuged at $6,000 \mathrm{~g}$ for $20 \mathrm{~min}$ at $4^{\circ} \mathrm{C}$ to remove insoluble material. Thereafter, the supernatant extracts were collected and protein concentration determined using the method of Bradford [37]. The extracts were frozen at $-80^{\circ} \mathrm{C}$ until western blot analyses were performed.

FABP, SREBP-1 and PPAR $\gamma$ protein expression were measured according to the method described by Doran et al. [38]. Briefly, $50 \mu \mathrm{g}$ total whole cell protein extracts were electrophoresed on SDS-PAGE (12\% resolving gel), transferred to a nitrocellulose membrane and probed overnight with a rabbit polyclonal anti-FABP, SREBP-1 and PPAR $\gamma$ antibody (Sigma, USA; 1:500, 1:1,000 and 1:2,000 dilutions, respectively). The membranes were then probed with a goat anti-rabbit IgG-horseradish peroxidase conjugate (Sigma, USA; 1:20,000) for $1 \mathrm{~h}$ at room temperature. Blots were developed using the SuperSignal West Pico Chemiluminescent Substrate system (Bio-Rad, USA) and imaged on microfilm for image analysis and densitometry. Signal intensity was quantified using Quantity One 1-D analysis software (Bio-Rad, USA).

\section{Statistical analyses}

The effects of dietary protein and body weight on serum parameters, adipocyte diameter, enzyme activities, and expression levels of lipid metabolism-related genes and protein were analyzed using the following model:

$$
Y_{i j l}=\mu+\alpha_{i}+\beta_{j}+\varepsilon_{i j l} \quad(i=1,2 ; j=1,2,3 ; l=1,2,3,4,5)
$$

where $\mu$ is a population parameter. $\alpha_{i}$ is effect of dietary protein, $\beta_{j}$ is effect of body weight, and $\varepsilon_{i j l}$ is random error or residual effects. The results were expressed as mean \pm SE and differences were considered significant when $P<0.05$ tested by 2 -way analysis of variance (ANOVA) with Statistical Packages for SAS 9.0.

\section{Results}

\section{Effect of dietary protein level on growth performance}

The effects of dietary protein level on growth performance in Wujin pigs are shown in table 3 . There were no significant differences in daily feed intake between the LP and HP groups during growth periods 15-30, 3060 and $60-100 \mathrm{~kg}$, but daily feed intake increased from $15 \mathrm{~kg}$ to $100 \mathrm{~kg}(\mathrm{P}<0.05)$. The daily gain in the HP group was significantly higher than in the LP group during the whole growth-finishing stages. The daily gain lessened with increasing body weight $(\mathrm{P}<0.05)$. The effects of dietary protein levels on the gain: feed ratio was significant during the $15-30$ and $30-60 \mathrm{~kg}$ periods.

\section{Effect of dietary protein level on carcass traits}

Dietary protein had no effect on carcass composition at $30 \mathrm{~kg}$ body weight, but affected the carcass composition significantly at $60 \mathrm{~kg}$ and $100 \mathrm{~kg}$ (table 4). Briefly, high dietary protein reduced the fat meat percentage and average backfat thickness $(P<0.05)$, but increased the lean meat percentage and loin eye area $(\mathrm{P}<0.05)$. With increasing body weight, lean meat percentage diminished, whereas fat meat percentage, loin eye area and average backfat thickness increased.

\section{Effect of dietary protein level on adipocyte size}

Figure 1 shows the effect of dietary protein on adipocyte size. High protein significantly reduced the adipocyte

Table 3 Effect of dietary protein on growth performance ${ }^{1}$

\begin{tabular}{lllll}
\hline & & $15-30 \mathrm{~kg}$ & $30-60 \mathrm{~kg}$ & $60-100 \mathrm{~kg}$ \\
\hline $\begin{array}{l}\text { Daily feed intake } \\
\text { (kg/d) }\end{array}$ & $\mathrm{LP}^{2}$ & $1.12 \pm 0.01^{\mathrm{a}}$ & $1.80 \pm 0.06^{\mathrm{b}}$ & $2.27 \pm 0.08^{\mathrm{C}}$ \\
& & & & \\
& $\mathrm{HP}$ & $1.13 \pm 0.04^{\mathrm{A}}$ & $1.82 \pm 0.02^{\mathrm{B}}$ & $2.24 \pm 0.02^{\mathrm{C}}$ \\
Daily gain (g/d) & $\mathrm{LP}$ & $392.11 \pm$ & $500.56 \pm$ & $461.49 \pm$ \\
& & $25.02^{\mathrm{a}}$ & $24.98^{\mathrm{b}}$ & $22.52^{\mathrm{C}}$ \\
& $\mathrm{HP}$ & $470.62^{ \pm} \pm$ & $583.65 \pm$ & $521.71 \pm$ \\
& & $23.68^{*} \mathrm{~A}$ & $31.87^{*} \mathrm{~B}$ & $29.14^{*} \mathrm{C}$ \\
Gain:feed ratio & $\mathrm{LP}$ & $0.35 \pm 0.01^{\mathrm{a}}$ & $0.28 \pm 0.01^{\mathrm{ab}}$ & $0.20 \pm 0.01^{\mathrm{b}}$ \\
& $\mathrm{HP}$ & $0.42 \pm 0.01^{*} \mathrm{~A}$ & $0.34 \pm 0.01^{*}$ & $0.24 \pm 0.01^{\mathrm{B}}$ \\
& & & &
\end{tabular}

${ }^{1}$ Means \pm SE without common letter differ significantly between body weight groups (lower case for LP group and upper case for HP).* indicating treatment differences at the same body weight $(P<0.05)$.

${ }^{2} \mathrm{LP}$, low protein diet.

${ }^{3} \mathrm{HP}$, high protein diet. 
Table 4 Effect of dietary protein on carcass composition ${ }^{1}$

\begin{tabular}{lllll}
\hline & & $30 \mathrm{~kg}$ & $60 \mathrm{~kg}$ & $100 \mathrm{~kg}$ \\
\hline Lean meat percentage(\%) & LP & $47.73 \pm 1.01^{\mathrm{a}}$ & $41.75 \pm 0.77^{\mathrm{b}}$ & $37.90 \pm 2.13^{\mathrm{C}}$ \\
& HP & $48.65 \pm 1.02^{\mathrm{A}}$ & $44.43 \pm 2.13^{\mathrm{B}}$ & $40.65 \pm 3.35^{\mathrm{C}}$ \\
Fat meat percentage(\%) & LP & $20.82 \pm 1.68^{\mathrm{a}}$ & $34.10 \pm 0.62^{\mathrm{b}}$ & $39.17 \pm 2.04^{* \mathrm{C}}$ \\
& HP & $18.68 \pm 1.41^{\mathrm{A}}$ & $31.53 \pm 1.66^{\mathrm{B}}$ & $36.00 \pm 1.08^{\mathrm{C}}$ \\
Lean eye area $\left(\mathrm{cm}^{2}\right)$ & LP & $10.96 \pm 0.12^{\mathrm{a}}$ & $17.69 \pm 1.52^{\mathrm{b}}$ & $21.53 \pm 1.66^{\mathrm{C}}$ \\
& HP & $11.66 \pm 1.24^{\mathrm{A}}$ & $20.02 \pm 1.59^{\mathrm{B}}$ & $23.76 \pm 1.22^{* \mathrm{C}}$ \\
Average backfat thickness (cm) & LP & $1.80 \pm 0.13^{\mathrm{a}}$ & $3.18 \pm 0.20^{*} \mathrm{a}$ & $4.75 \pm 0.16^{*} \mathrm{a}$ \\
\hline
\end{tabular}

${ }^{1}$ Symbols/abbreviations as for table 3.

size at 60 and $100 \mathrm{~kg}(\mathrm{P}<0.05)$. Size in both groups increased with increasing body weight $(\mathrm{P}<0.05)$.

Effect of dietary protein level on serum parameters

Serum concentrations of FFA and TG were increased $(\mathrm{P}<0.05)$ by high dietary protein at 60 and $100 \mathrm{~kg}$ body weights. Dietary protein had no effect on serum insulin and glucose concentrations at any body weight (table 5). FFA in both groups was highest at $60 \mathrm{~kg}$ compared with $30 \mathrm{~kg}$ and $100 \mathrm{~kg}$. TG in both groups diminished with increasing body weight.

\section{Effect of dietary protein level on enzyme activities}

High dietary protein significantly decreased the activities of ACC, FAS, ME and G-6-PDH at 60 and $100 \mathrm{~kg}$, increased the activities of LPL and CPT-1 at $60 \mathrm{~kg}$, but reduced activities of CPT-1 and LPL at $100 \mathrm{~kg}(\mathrm{P}<0.05)$ (table 6). However, HSL activity was decreased markedly at $60 \mathrm{~kg}$ but increased markedly at $100 \mathrm{~kg}$. Lipid metabolism-related enzyme activities were not notably affected by dietary protein at $30 \mathrm{~kg}$. The activities of ACC, FAS, ME and G-6-PDH enzymes in both LP and HP groups were up-regulated in all 3 weight groups, whereas activities of

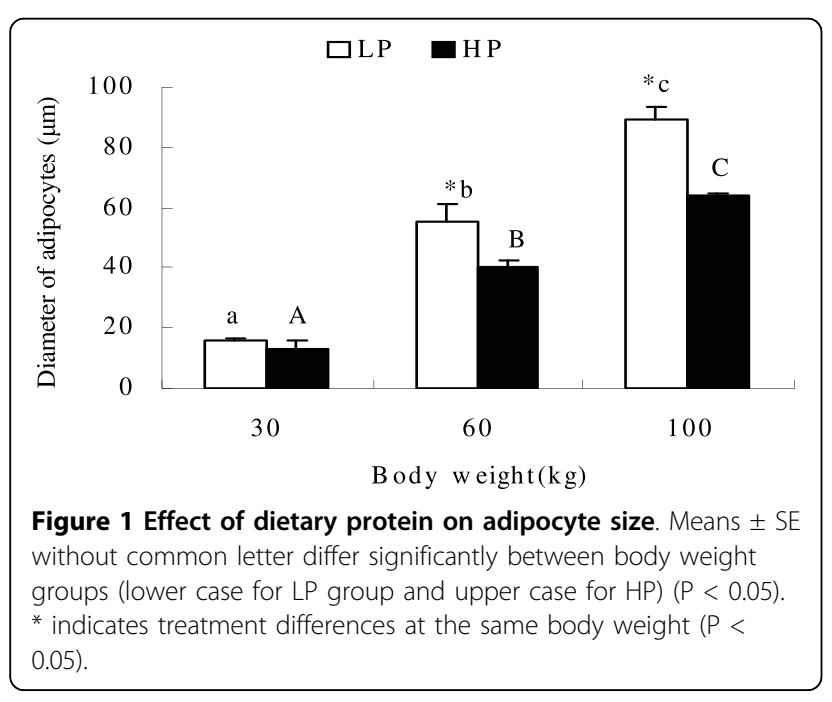

LPL, HSL and CPT-1 enzymes in both LP and HP groups at $60 \mathrm{~kg}$ were higher than at $30 \mathrm{~kg}$ and $100 \mathrm{~kg}$. Effect of dietary protein level on mRNA abundance of genes

High dietary protein decreased levels of ACC, FAS and SREBP-1 mRNAs $(\mathrm{P}<0.05)$ at 60 and $100 \mathrm{~kg}$, promoted mRNA expression of LPL, CPT-1, PPAR $\gamma$ and A-FABP at $60 \mathrm{~kg}(\mathrm{P}<0.05)$ and reduced mRNA expression of these genes at $100 \mathrm{~kg}(\mathrm{P}<0.05)$. HSL mRNA expression was reduced at $60 \mathrm{~kg}$ but was increased at $100 \mathrm{~kg}$ (figures 2 and 3). However, dietary protein did not significantly affect mRNA expression of these genes at $30 \mathrm{~kg}$, with the exception that FAS mRNA level was increased by high dietary protein. The mRNA abundance of ACC, FAS, SREBP-1 and PPAR $\gamma$ in LP and HP groups increased as weight increased from $30 \mathrm{~kg}$ to $100 \mathrm{~kg}$, but mRNA abundance of LPL, A-FABP, HSL and CPT-1 in both groups was higher at $60 \mathrm{~kg}$ than at $30 \mathrm{~kg}$ and $100 \mathrm{~kg}$.

Effect of dietary protein level on protein expression level High dietary protein significantly reduced SREBP-1 protein expression at 60 and $100 \mathrm{~kg}$. Expression of PPAR $\gamma$ and A-FABP was increased at $60 \mathrm{~kg}$, but decreased at 100 $\mathrm{kg}(\mathrm{P}<0.05)$. The protein abundance of SREBP-1 and PPAR $\gamma$ increased with increasing body weight. Dietary protein did not significantly affect the protein expression of these genes at $30 \mathrm{~kg}$ body weight (figure 4).

\section{Discussion}

Pigs and humans share numerous physiological and phenotypic similarities with regard to fat deposition [20], and pigs have been used extensively as a biomedical research model for various human physiological conditions [21]. Obesity is the surplus fat deposition in the adipose tissue associated with nutrition [39]. Accumulation of fat may increase even during a period of decreased fat synthesis if there is simultaneously an even greater decrease in the turnover and catabolism of adipose tissue fatty acids. High dietary protein decreases fat deposition in adipose tissue [22-26,40-44]. However, there is little information on how dietary protein regulates the balance between 
Table 5 Effect of dietary protein on serum parameters ${ }^{1}$

\begin{tabular}{|c|c|c|c|c|}
\hline & & $30 \mathrm{~kg}$ & $60 \mathrm{~kg}$ & $100 \mathrm{~kg}$ \\
\hline \multirow[t]{2}{*}{ Free fatty acids $(\mu \mathrm{Eq} / \mathrm{L})$} & $L P$ & $238.42 \pm 12.33^{\mathrm{a}}$ & $320.00 \pm 17.11^{\mathrm{b}}$ & $240.23 \pm 11.32^{c}$ \\
\hline & HP & $253.82 \pm 11.22^{\mathrm{A}}$ & $410.34 \pm 16.22^{* B}$ & $320.24 \pm 12.42^{* C}$ \\
\hline \multirow[t]{2}{*}{ Triacylglycerol (mmol/L) } & LP & $0.38 \pm 0.03^{\mathrm{a}}$ & $0.47 \pm 0.04^{\mathrm{ab}}$ & $0.51 \pm 0.02^{\mathrm{b}}$ \\
\hline & $\mathrm{HP}$ & $0.40 \pm 0.02^{\mathrm{A}}$ & $0.63 \pm 0.07^{* A B}$ & $0.75 \pm 0.03^{* B}$ \\
\hline \multirow[t]{2}{*}{ Glucose (mg/dL) } & LP & $64.62 \pm 3.77^{\mathrm{a}}$ & $65.09 \pm 2.11^{\mathrm{a}}$ & $66.22 \pm 5.76^{a}$ \\
\hline & HP & $64.73 \pm 4.01^{\mathrm{A}}$ & $65.49 \pm 1.76^{\mathrm{A}}$ & $66.42 \pm 2.99^{A}$ \\
\hline \multirow[t]{2}{*}{ Insulin ( $\mu \mid \mathrm{U} / \mathrm{mL})$} & LP & $6.76 \pm 0.11^{\mathrm{a}}$ & $7.99 \pm 0.10^{\mathrm{a}}$ & $7.52 \pm 0.17^{\mathrm{a}}$ \\
\hline & HP & $6.63 \pm 0.18^{A}$ & $7.49 \pm 0.11^{\mathrm{A}}$ & $7.22 \pm 0.09^{A}$ \\
\hline
\end{tabular}

${ }^{1}$ Symbols/abbreviations as for table 3

synthesis, uptake, and transport of fatty acids. Therefore, in this study, we used the fatty Wujin pig as a model to investigate the regulating mechanisms of dietary protein on lipid metabolism in adipose tissue.

Previous studies on the market weight of swine have demonstrated that lower protein diets reduced $[25,40]$ or had no effect $[23,41]$ on weight gain and gain-to-feed ratio, but our observations were that higher dietary protein level increased the daily weight gain of Wujin pigs. This discrepancy may be due to the different porcine breeds used in the different studies. However, our results are the first report on the influence of dietary protein levels on growth performance of the Wujin pig, a typical fatty local Chinese breed of swine. Our data, therefore, provide the basis for studying differences in growth performance between Wujin pigs and other breeds of swine.

Increasing dietary protein has been well documented to decrease adipose tissue fat deposition and carcass backfat thickness in growing pigs [23-25,40,41], and our results are consistent with this. No differences in serum glucose and insulin were detected in Wujin pigs fed $14 \%$ versus $18 \%$ dietary protein in the present study, which is in agreement with reports from several other laboratories [45,46]. However, Caperna et al. [47] and Atinmo et al. [48] reported that feeding low protein diets to young pigs produced lower serum glucose and insulin levels than did high protein diets. High dietary protein has been reported to enhance serum FFA and TG contents in the late growing stage of pigs [49-51,38], an observation also made in the present study, especially at $60 \mathrm{~kg}$ and $100 \mathrm{~kg}$ body weights. Serum FFA results mainly from release from adipose tissue catalyzed by HSL or from hepatic triglycerides through the hydrolysis of LPL circulation. These data suggest that high dietary protein facilitates the release and transport of FFA from adipose tissue.

\section{Table 6 Effect of dietary protein level on adipose tissue enzyme activities ${ }^{\mathbf{1}}$}

\begin{tabular}{|c|c|c|c|c|}
\hline & & $30 \mathrm{~kg}$ & $60 \mathrm{~kg}$ & $100 \mathrm{~kg}$ \\
\hline \multirow{2}{*}{$\begin{array}{l}\text { ACC } \\
\text { (nmol } \mathrm{HCO}_{3} / \mathrm{min} / \mathrm{mg} \text { protein) }\end{array}$} & $L P$ & $28.35 \pm 1.12^{\mathrm{a}}$ & $40.03 \pm 2.00^{* a b}$ & $47.43 \pm 1.24^{* b}$ \\
\hline & $\mathrm{HP}$ & $24.12 \pm 1.90^{\mathrm{A}}$ & $26.04 \pm 1.91^{\mathrm{AB}}$ & $34.13 \pm 1.25^{B}$ \\
\hline \multirow{2}{*}{$\begin{array}{l}\text { FAS } \\
\text { (nmol NADPH/min/mg protein) }\end{array}$} & $L P$ & $33.41 \pm 1.32^{\mathrm{a}}$ & $69.03 \pm 3.14^{*} \mathrm{~b}$ & $72.23 \pm 3.42^{*} \mathrm{~b}$ \\
\hline & $\mathrm{HP}$ & $35.34 \pm 1.09^{\mathrm{A}}$ & $54.04 \pm 1.80^{B}$ & $60.41 \pm 2.20^{B}$ \\
\hline \multirow{2}{*}{$\begin{array}{l}\text { ME } \\
\text { (nmol NADPH/min/mg protein) }\end{array}$} & LP & $253.43 \pm 14.23^{\mathrm{a}}$ & $290.33 \pm 12.44^{*} b$ & $320.34 \pm 13.42^{* b}$ \\
\hline & $\mathrm{HP}$ & $234.12 \pm 12.09^{A}$ & $240.43 \pm 11.90^{\mathrm{A}}$ & $253.11 \pm 13.20^{\mathrm{A}}$ \\
\hline \multirow{2}{*}{$\begin{array}{l}\text { G-6-PDH } \\
\text { (nmol NADPH/min/mg protein) }\end{array}$} & $\mathrm{LP}$ & $189.42 \pm 12.34^{\mathrm{a}}$ & $233.32 \pm 17.43^{*} b$ & $290.54 \pm 14.67^{* c}$ \\
\hline & $\mathrm{HP}$ & $177.23 \pm 12.12^{\mathrm{A}}$ & $168.01 \pm 18.65^{\mathrm{A}}$ & $278.39 \pm 15.77^{B}$ \\
\hline \multirow{2}{*}{$\begin{array}{l}\text { LPL } \\
\text { (mmol oleic acid/h/g tissue) }\end{array}$} & LP & $29.56 \pm 1.45^{\mathrm{a}}$ & $30.43 \pm 1.22^{\mathrm{a}}$ & $29.21 \pm 1.88^{\mathrm{a}}$ \\
\hline & $\mathrm{HP}$ & $27.43 \pm 1.34^{\mathrm{A}}$ & $40.11 \pm 1.13^{*} \mathrm{~B}$ & $36.43 \pm 1.01^{* B}$ \\
\hline \multirow{2}{*}{$\begin{array}{l}\text { HSL } \\
\text { (mU/mg protein) }\end{array}$} & $L P$ & $3.62 \pm 0.16^{a}$ & $8.02 \pm 0.08^{* b}$ & $4.21 \pm 0.06^{\mathrm{a}}$ \\
\hline & $\mathrm{HP}$ & $3.75 \pm 0.13^{A}$ & $6.43 \pm 0.02^{B}$ & $6.43 \pm 0.06^{* B}$ \\
\hline \multirow{2}{*}{$\begin{array}{l}\text { CPT-1 } \\
\text { (nmol palmitate/min/mg protein) }\end{array}$} & $L P$ & $2.17 \pm 0.09^{a}$ & $6.34 \pm 0.11^{b}$ & $5.94 \pm 0.10^{b}$ \\
\hline & HP & $2.13 \pm 0.05^{\mathrm{A}}$ & $6.02 \pm 0.09 * B$ & $3.12 \pm 0.06^{* A}$ \\
\hline
\end{tabular}

${ }^{1}$ Symbols/abbreviations as for table 3. 

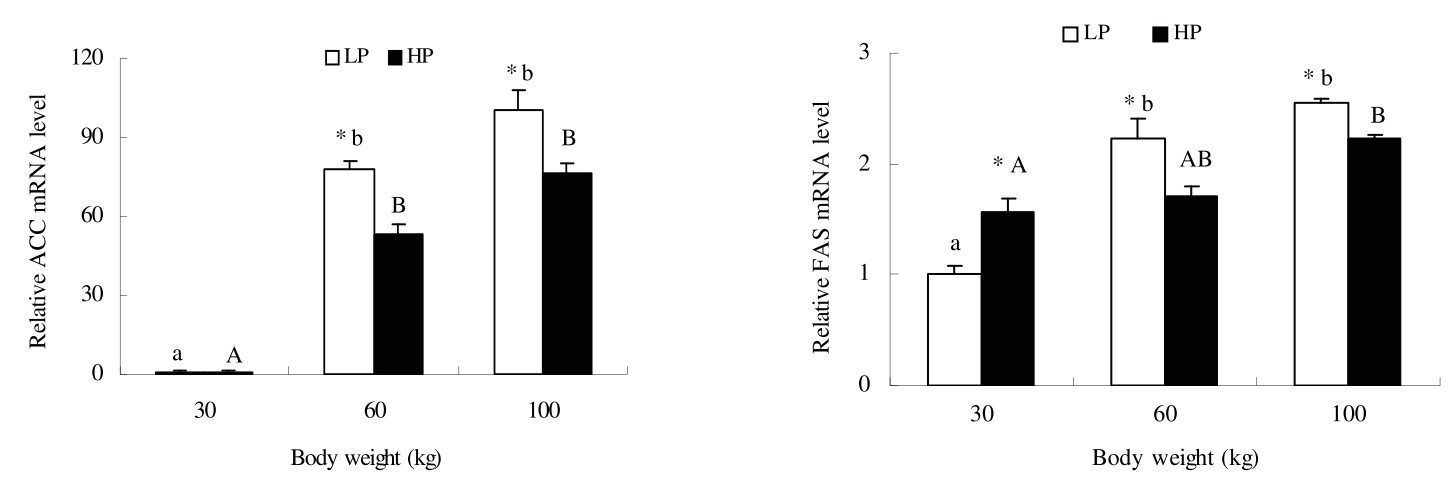

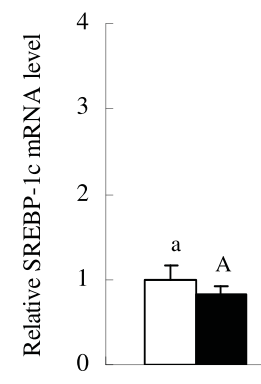

30
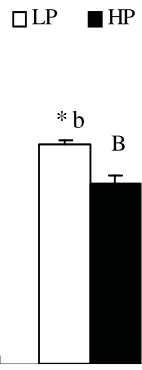

60

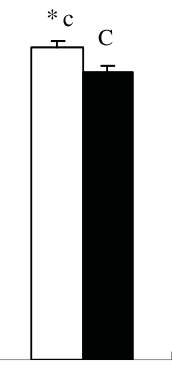

100

Body weight $(\mathrm{kg})$

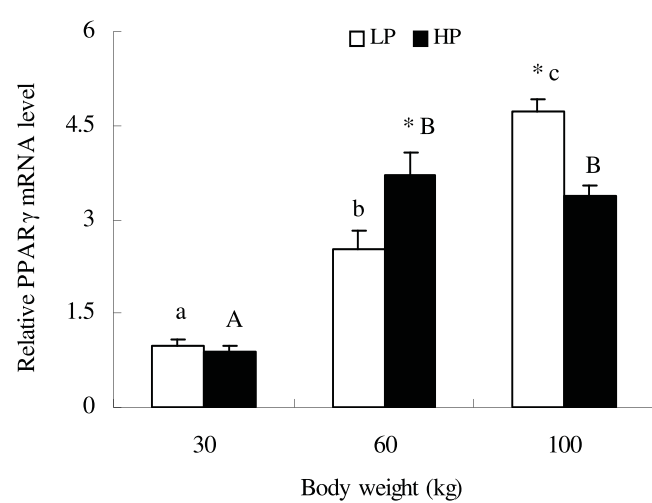

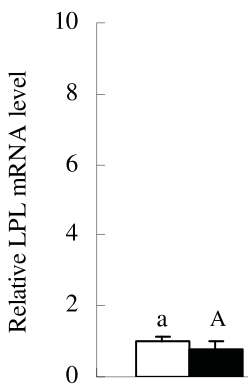

30 $\square \mathrm{LP} \quad \mathbf{H P}$

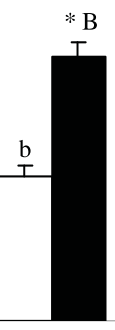

60

Body weight $(\mathrm{kg})$

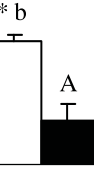

100

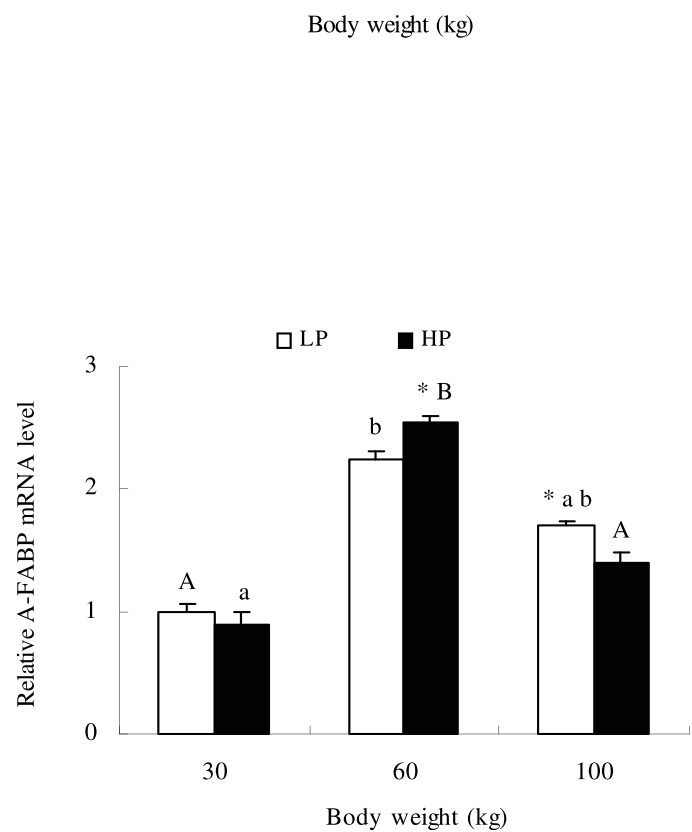

Body weight $(\mathrm{kg})$

Figure 2 Relative mRNA abundance of lipogenic genes in adipose tissues at 30, 60 and $100 \mathrm{~kg}$ body weights of pigs fed high and low dietary protein, based on extraction of total RNA and subsequent real-time PCR analysis. Means \pm SE without common letter differ

significantly between body weight groups (lower case for LP group and upper case for HP). ${ }^{*}$ indicates treatment differences at the same body weight $(P<0.05)$. 


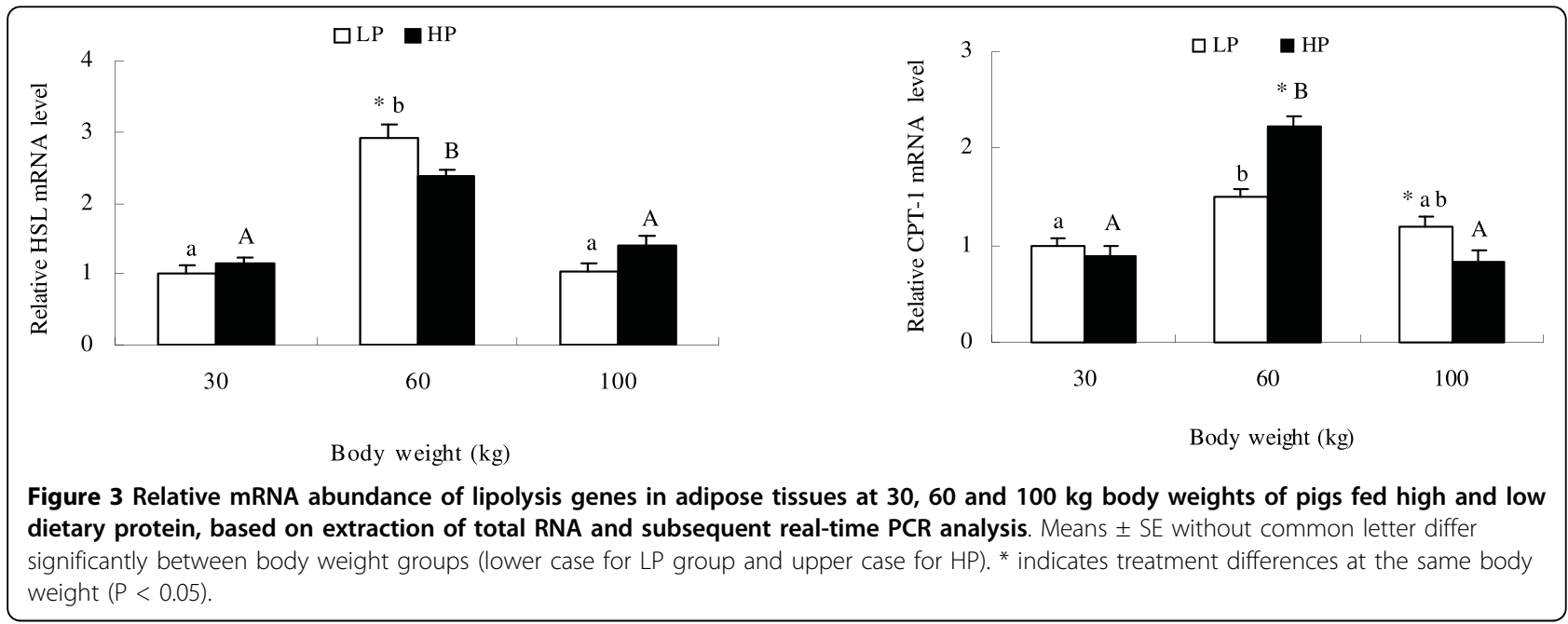

Mersmann et al. [52] reported a marked increase in adipocyte size accompanied by an increase in the size of the central lipid droplets with age. The present study showed that high protein reduced adipocyte size, with differences increasing with increasing body weight. Fat deposition is mainly associated with lipogenic capacity in adipose tissue. ACC is a key rate limiting enzyme in the de novo pathway of fatty acid synthesis [6]. The entire pathway of palmitate synthesis from malonyl-CoA is catalyzed by FAS which is a key determinant of the maximal capacity of a tissue to synthesize fatty acids by the de novo pathway $[7,8]$. ME and G-6-PDH are recognized to be the main enzymes involved in supplying $\mathrm{NADH}$, the co-enzyme required for reductive biosynthesis of fatty acids [9-11]. SREBP-1, as a key transcription factor, regulates the expression of lipogenic genes such as FAS and ACC under different nutritional states, and is a candidate gene for determination of lipogenic capacity [12-14,53]. The present study showed that high dietary protein reduced the mRNA abundance or protein expression level of lipogenic genes such as ACC, ME, G-6-PDH and SREBP-1 during the whole growth period. Although FAS mRNA expression and enzyme activity were up-regulated at $30 \mathrm{~kg}$ by high dietary protein, the FAS gene was down-regulated at 60 and $100 \mathrm{~kg}$.

Some reports have indicated that reductions in lipogenic activity are typically associated with reductions in activities of enzymes such as ACC, FAS and ME [6,8,38,54-58]. The down-regulated expression of these lipogenic genes means there is a reduced capacity for de novo synthesis of FFA. Additionally, our data show that gene mRNA expression paralleled enzyme activity and protein expression, in agreement with the report of Morris et al. [59]. Taken altogether, these data indicate that high dietary protein reduces the capacity of adipose tissue for de novo synthesis of FFA, leading to decreasing fat accumulation.

Fat deposition is determined by a complex balance between lipogenic, lipolytic enzymes and fatty acids transport, as well as fatty acid utilization. LPL is the major enzyme responsible for hydrolysis of triglycerides in chylomicrons and VLDL to provide free fatty acids for tissue utilization or storage [12]. LPL is abundant in adipose tissue, and its gene expression correlates strongly with the uptake of lipid fuels by the tissue. Therefore, LPL is considered the key factor determining lipid deposition in tissues, and has been described as the 'metabolic gatekeeper' [60-62]. Our results show that high dietary protein increased LPL mRNA expression and enzyme activity at $60 \mathrm{~kg}$, which suggests that more FFA was released from VLDL at this weight. This situation was reversed at $100 \mathrm{~kg}$ body weight.

PPAR $\gamma$ is a member of the nuclear receptor superfamily and regulates the expression of several genes encoding proteins involved in adipocyte differentiation and fat deposition [17]. It has been reported to promote LPL and FABP gene expression and to suppress the HSL gene [17]. HSL cleaves fatty acids from intracellular triacylglycerol for oxidation and export [12]. CPT-1 initiates mitochondrial import in the degradation of fatty acids through mitochondrial $\beta$-oxidation [14]. The present study has shown that PPAR $\gamma, \mathrm{A}-\mathrm{FABP}$ and CPT- 1 and mRNA and protein expression were up-regulated by high dietary protein at $60 \mathrm{~kg}$ and down-regulated at 100 $\mathrm{kg}$, with the opposite occurring with HSL. This suggests that high dietary protein decreases the release of FFA from adipose tissue at $60 \mathrm{~kg}$. FFA bind to FABP and are transported for esterification and oxidation in adipose tissue [18]. Therefore, high dietary protein regulates FFA uptake, transport and lipolysis differently at different growth stages. 

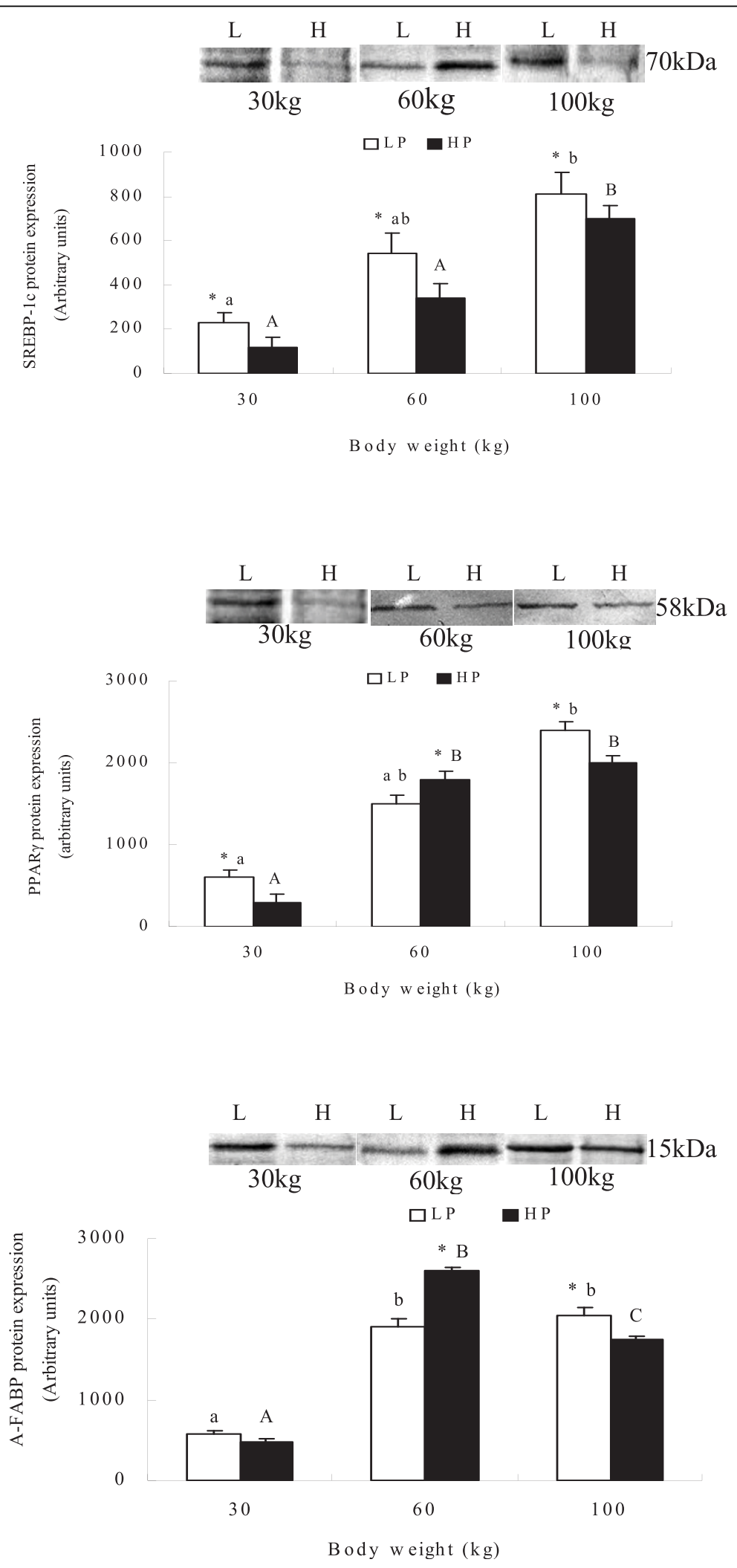

Figure 4 Protein expressions in adipose tissues at 30,60 and $100 \mathrm{~kg}$ body weights of pigs fed high and low dietary protein. Means \pm SE without common letter differ significantly between age groups (lower case for LP group and upper case for HP). * indicates treatment differences at the same body weight $(P<0.05)$. 


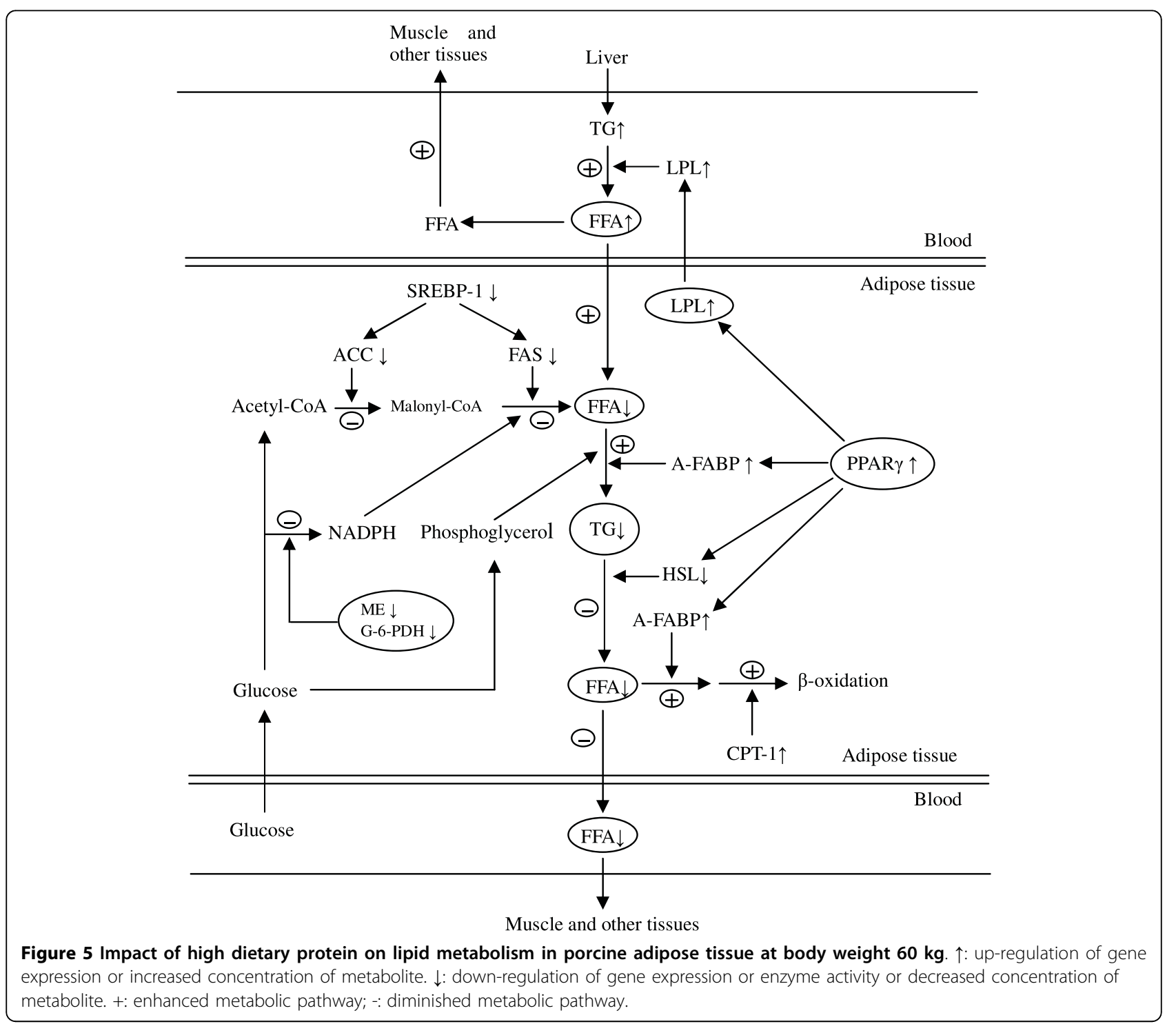

The rate of lipogenesis in adipose tissue has been found to decrease during aging $[63,64]$. This decreased lipogenesis accompanying maturity is of particular interest because it has been noted for many years that fat deposition increases with age [65]. Thus, an apparent contradiction exists: fat accumulation is increasing when the rate of lipogenesis is decreasing. This may be due to the balance between synthesis and degradation. A net increase in the accumulation of fat could result even during a period of decreased fat synthesis if there is simultaneously an even greater decrease in the turnover and catabolism of adipose tissue fatty acids [66]. However, some reports indicate that lipogenic activity is greatest at 4 months of age in pig adipose tissue $[53,67]$. Other reports have shown that lipogenic enzyme activities generally decreased with increasing weight in pigs $[57,52,68]$.

The above studies on fat deposition in porcine adipose tissue have focused mainly on lipogenesis, and there is little information on lipolysis. Our study is the first to investigate in detail the developmental changes in lipid metabolism-related gene expression and enzyme activity controlled by lipogenic and lipolytic genes throughout the growth-finishing stages. Our results have shown that the enzyme activities/protein expression levels and gene expression of ME, ICD, G-6-PDH, ACC, FAS and SREBP1 increased with increasing body weight. However, mRNA and protein expression of HSL, LPL, A-FABP and CPT-1 activity peaked at $60 \mathrm{~kg}$, indicating that different lipid metabolic activities exist at different body weights. 


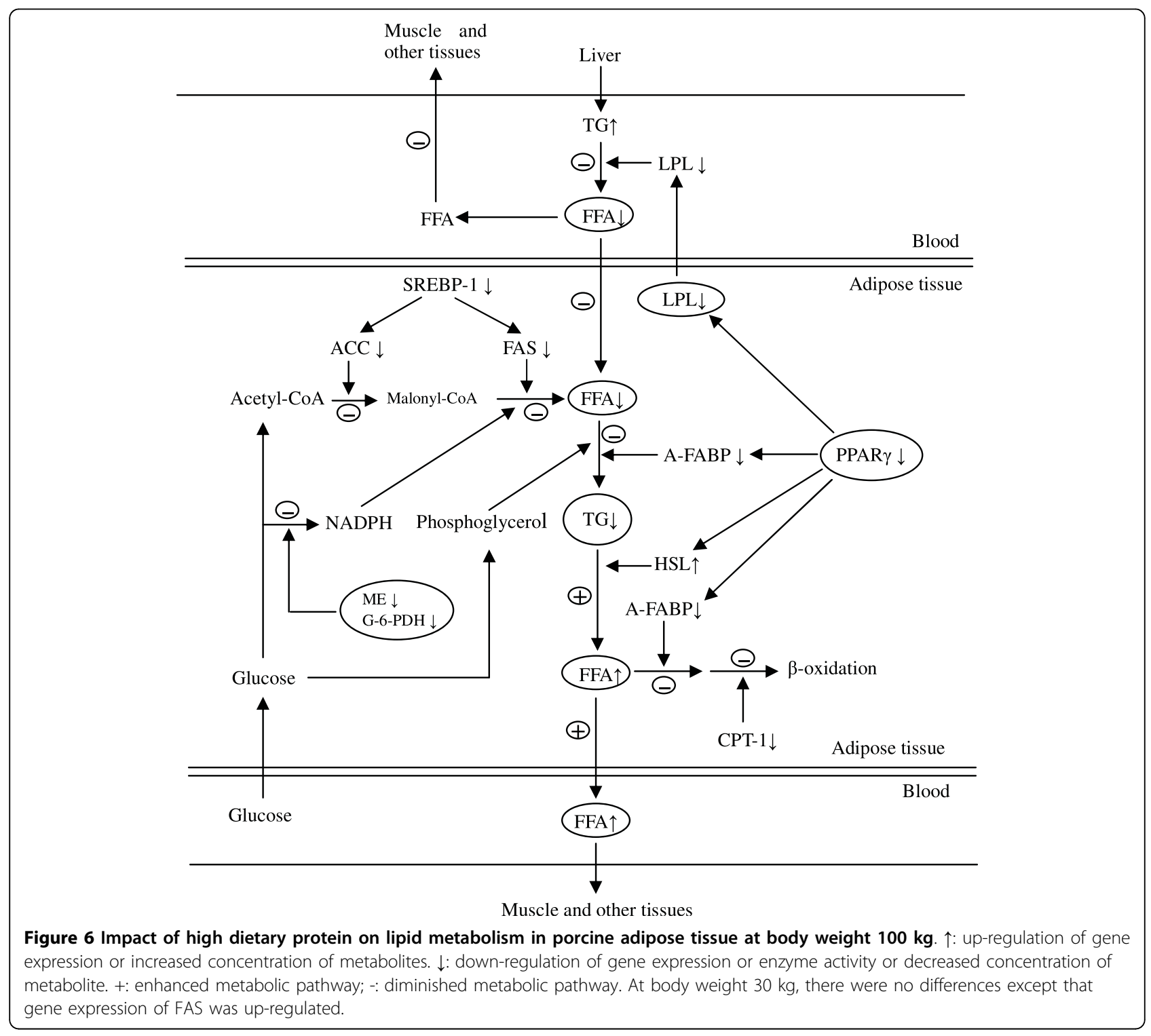

\section{Conclusion}

In all, our observations have indicated that the mechanism of down-regulation of synthesis of triglyceride in adipose tissue by high dietary protein is mainly by inhibition of lipogenic gene expression. It appears that high dietary protein regulates FFA uptake, transport and lipolysis differently at different growth stages. High dietary protein promoted FFA uptake and oxidation in adipose tissue at $60 \mathrm{~kg}$, but increased FFA release from adipose tissue to serum, and decreased FFA oxidation in adipose tissue at 30 and $100 \mathrm{~kg}$ (figures 5 and 6).

\section{Abbreviations}

RT-PCR: reverse transcription and polymerase chain reaction; SREBP-1c: sterol regulatory element binding protein $1 C$; FAS: fatty acid synthase; ACC: acetylCoA carboxylase; A-FABP: Adipocyte (A) - fatty acid binding proteins; CPT-1B: carmitine palmtoyltransferase-1B; HSL: hormone sensitive lipase; LPL: lipoprotein lipase; ME: malic enzyme; G-6-PDH: glucose-6-phosphate dehydrogenase; PPAR $\gamma$. peroxisome proliferator-activated receptor $\gamma$, FFA: free fatty acid(s); TG: triacylglycerol.

\section{Acknowledgements}

This work was supported by the Key Project of the Natural Science Foundation of Yunnan Province (Project No. 2005C0008Z) and National Key Foundation Research Development Project of China (973 Project, No.2007CB116201).

\section{Authors' contributions}

ZSM analyzed the data and wrote this manuscript. WJ and SXL carried out the experiments. ZX and GCR participated in the experimental design. GSZ designed the experiments and edited the manuscript. All authors read and approved the final manuscript.

\section{Competing interests}

The authors declare that they have no competing interests. 
Received: 1 August 2009

Accepted: 21 January 2010 Published: 21 January 2010

\section{References}

1. Allee $G L$, Romsos D, Leveille GA, Baker DH: Influence of age on in vitro lipid biosynthesis and enzymatic activity in pig adipose tissue. Proc Soc Exp Biol Med 1971, 137:449-452.

2. O'Hea EK, Leveille GA: Lipid biosynthesis and transport in the domestic chick (Gallus domesticus). Comp Biochem Physiol 1969, 30:149-159.

3. O'Hea EK, Leveille GA: Significance of adipose tissue and liver as sites of fatty acid synthesis in the pig and the efficiency of utilization of various substrates for lipogenesis. J Nutr 1969, 99:338-344.

4. Steffen DG, Brown LJ, Mersmann HJ: Ontogenic development of swine (Sus domesticus) adipose tissue lipases. Comp Biochem Physiol B 1978, 59:195-201.

5. Hirsch J, Han PW: Cellularity of rat adipose tissue: effects of growth, starvation, and obesity. J Lipid Res 1969, 10:77-82.

6. Liu CY, Grant AL, Kim KH, Mills SE: Porcine somatotropin decreases acetylCoA carboxylase gene expression in porcine adipose tissue. Domest Anim Endocrinol 1994, 11:125-132.

7. Smith S, Witkowski A, Joshi AK: Structural and functional organization of the animal fatty acid synthase. Prog Lipid Res 2003, 42:289-317.

8. Clarke SD: Regulation of fatty acid synthase gene expression: an approach for reducing fat accumulation. J Anim Sci 1993, 71:1957-1965.

9. Wise E, Ball EG: Malic enzyme and lipogenesis. Proc Natl Acad Sci 1964, 52:1255-1263.

10. Young JW, Shrago E, Lardy HA: Metabolic control of enzymes involved in lipogenesis and gluconeogenesis. Biochemistry 1964, 3:1687-1692.

11. Bauman DE: Intermediary metabolism of adipose tissue. Fed Proc 1976, 35:2308-2313.

12. Mersmann $\mathrm{HJ}$ : Lipoprotein and hormone-sensitive lipases in porcine adipose tissue. J Anim Sci 1998, 76:1396-1404

13. DeBerardinis RJ, Lum JJ, Thompson CB: Phosphatidylinositol 3-kinasedependent modulation of carnitine palmitoyltransferase $1 \mathrm{~A}$ expression regulates lipid metabolism during hematopoietic cell growth. J Biol Chem 2006, 281:37372-37380.

14. Yin $L$, Zhang $Y$, Hillgartner FB: Sterol regulatory element-binding protein-1 interacts with the nuclear thyroid hormone receptor to enhance AcetylCoA Carboxylase- $\alpha$ transcription in hepatocytes. J Biol Chem 2002, 277:19554-19565.

15. Stoeckman AK, Towle HC: The Role of SREBP-1c in Nutritional Regulation of Lipogenic Enzyme Gene Expression. J Biol Chem 2002, 277:27029-27035.

16. Brown MS, Goldstein JL: A proteolytic pathway that controls the cholesterol content of membranes, cells, and blood. Proc Natl Acad Sci 1999, 96:11041-11048.

17. Grindflek E, Sundvold H, Lien S, Rothschild MF: Rapid communication: physical and genetic mapping of the Peroxisome Proliferator Activated Receptor $\gamma$ (PPAR $\gamma$ ) gene to porcine chromosome 13. J Anim Sci 2000, 78:1391-1392.

18. Elizabeth RS, Judith S: The Adipocyte fatty acid-binding protein binds to membranes by electrostatic interactions. J Biol Chem 1999, 274:35325-35330.

19. Yang HG, Ma CW, Qiao FD, Song Y, Du M: Lipolysis in intramuscular lipids at processing of traditional Xuanwei ham. Meat Sci 2005, 71:670-675

20. Tumbleson ME, Schook LB: Advances in Swine in Biomedical Research New York: Plenum Press 1996, 1-2.

21. Houpt KA, Houpt TR, Pond WG: The pig as a model for the study of obesity and of control of food intake: a review. Yale J Biol Med 1979, 52:307-329.

22. Dunshea FR, King RH, Campbell RG: Interrelationship between dietray protein and ractopamine on protein and lipid depostition in finishing gilts. J Anim Sci 1993, 71:2931-2941.

23. Adeola O, Young LG: Dietary protein-induced changes in porcine muscle respiration, protein synthesis and adipose tissue metabolism. J Anim Sci 1989, 67:664-673.

24. Cromwell GL, Cline TR, Crenshaw JD: The dietary protein and lysine requirements of barrows and gilts. NCR-42 Committee on Swine Nutrition. J Anim Sci 1993, 71:510-1519.
25. Kerr BJ, Easter RA: Effect of feeding reduced protein, amino acid supplemented diets on nitrogen and energy balance in grower pigs. J Anim Sci 1995, 73:3000-3008.

26. Johansen S, Hakansson J, Andersson K: Effect of selecting for increased lean tissue growth rate in swine on low or high dietary protein levels. J Anim Sci 1993, 71:1203-1208.

27. Zhang HF, Zhang ZY: Chinese feeding standards for local breed pig Chinese Agricultural Publisher, 1 1998, 65-66.

28. Etherton TD, Chung CS: Preparation, characterization, and insulin sensitivity of isolated swine adipocytes: comparison with adipose tissue slices. J Lipid Res 1981, 22:1053-1059.

29. Chang HC, Seidman I, Teebor G, Lane DM: Liver acetyl-CoA-carboxylase and fatty acid synthetase: relative activities in the normal state and in hereditary obesity. Biochem Biophys Res Commun 1967, 28:682-686.

30. Chakrabarty K, Leveille GA: Acetyl-CoA carboxylase and fatty acid synthetase activities in liver and adipose tissue of meal-fed rats. Proc Soc Exp Biol Med 1969, 131:1051-1054

31. Ochoa S: "Malic" enzyme. Methods in Enzymology Academic Press, New YorkColowick SP, Kaplan NO 1955, 1:739-753.

32. Glock GE, Mclean P: Further studies on the properties and assay of glucose-6-phosphate dehydrogenase and 6-phosphogluconate dehydrogenase of rat liver. Biochem J 1953, 55:400-408.

33. Martin DB, Horning MG, Vagelos PR: Fatty acid synthesis in adipose tissue. I. Purification and properties of a long chain fatty acid-synthesizing system. J Biol Chem 1961, 236:663-668.

34. Ingle DL, Bauman DE, Mellenberger RW, Johnson DE: Lipogenesis in the ruminant: effect of fasting and refeeding on fatty acid synthesis and enzymatic activity of sheep adipose tissue. J Nutr 1973, 103:1479-1488.

35. Osterlund TB, Danielsson ED, Contreras JA, Edren G, Davis RC, Schotz MC, Holm C: Domain-structure analysis of recombinant rat hormone-sensitive lipase. Biochem J 1996, 319:411-420.

36. Bieber $\mathrm{LL}$, Abraham $\mathrm{T}$, Helmrath $\mathrm{T}$ : A rapid spectrophotometric assay for carnitine palmitoyltransferase. Anal Biochem 1972, 50:509-518.

37. Bradford MM: A rapid and sensitive method for the quantitation of microgram quantities of protein utilizing the principle of protein-dye binding. Anal Biochem 1976, 72:248-254.

38. Doran O, Moule SK, Teye GA, Whittington FM, Hallett KG, Wood JD: A reduced protein diet induces stearoyl-CoA desaturase protein expression in pig muscle but not in subcutaneous adipose tissue: relationship with intramuscular lipid formation. Br J Nutr 2006, 95:609-617.

39. Chagnon YC, Rankinen T, Snyder EE, Weinagel SJ, Perusse L, Bouchard C: The human obesity gene map: the 2002 update. Obes Res 2003, 11:313-367.

40. Mitchell AD, Solomon MB, Steele NC: Influence of level of dietary protein or energy on effects of ractopamine in finishing swine. J Anim Sci 1991, 69:4487-4495.

41. Kerr BJ, Southern LL, Bidner TD, Friesen KG, Easter RA: Influence of dietary protein level, amino acid supplementation, and dietary energy levels on growing-finishing pig performance and carcass composition. J Anim Sci 2003, 81:3075-3087.

42. Lopez J, Goodband RD, Allee GL, Jesse GW, Nelssen JL, Tokach MD, Spiers D, Becker BA: The effects of diets formulated on an ideal protein basis on growth performance, carcass characteristics, and thermal balance of finishing gilts housed in a hot, diurnal environment. J Anim Sci 1994, 72:367-379.

43. Figueroa JL, Lewis AJ, Miller PS, Fischer RL, Diedrichsen RM: Growth, carcass traits, and plasma amino acid concentrations of gilts fed lowprotein diets supplemented with amino acids including histidine, isoleucine, and valine. J Anim Sci 2003, 81:1529-1537.

44. Noble J, Henry Y, Dubois S: Effect of protein and lysine levels in the diet on body gain composition and energy utilization in growing pigs. J Anim Sci 1987, 65:717-726.

45. Seve B, Ballevre O, Ganier P, Noblet J, Prugnaud J, Obled C: Recombinant porcine somatotropin and dietary protein enhance protein synthesis in growing pigs. J Nutr 1993, 123:529-540.

46. Brameld JM, Atkinson JL, Saunders JC, Pell JM, Buttery PJ, Gilmour RS: Effects of growth hormone administration and dietary protein intake on insulin-like growth factor I and growth hormone receptor mRNA Expression in porcine liver, skeletal muscle, and adipose tissue. J Anim Sci 1996, 74:1832-1841. 
47. Caperna TJ, Steele NC, Komarek DR, McMurtry JP, Rosebrough RW, Solomon MB, Mitchell AD: Influence of dietary protein and recombinant porcine somatotropin administration in young pigs: growth, body composition and hormone status. J Anim Sci 1990, 68:4243-4252.

48. Atinmo T, Baldijao C, Pond WG, Barnes RH: Plasma insulin levels in weaned pigs fed protein or energy restricted diets. J Nutr 1976 106:1654-1658.

49. Ramsay TG, Mitchell AD: Impact of dietary protein content on uncoupling protein mRNA abundance in swine. Comp Biochem Physiol B 2008, 149:562-571.

50. Gomez RS, Lewis AJ, Miller PS, Chen HY: Growth performance, diet apparent digestibility, and plasma metabolite concentrations of barrows fed corn-soybean meal diets or low-protein, amino acid-supplemented diets at different feeding level. J Anim Sci 2002, 80:644-653.

51. Matthews JO, Southern LL, Pontif JE, Higbie AD, Bidner TD: Interactive effects of betaine, crude protein, and net energy in finishing pigs. J Anim Sci 1998, 76:2444-2455.

52. Mersmann HJ, Goodman JR, Brown LJ: Development of swine adipose tissue: morphology and chemical composition. J Lipid Res 1975, 16:269-279.

53. Kim JB, Sarraf P, Wright M, Yao KM, Mueller E, Solanes G, Lowell BB, Spiegelman BM: Nutritional and insulin regulation of fatty acid synthetase and leptin gene expression through ADD1/SREBP1. I Clin Invest 1998, 101:1-9.

54. Jacques M, Maryline K, Philippe P: Comparative study of in vitro lipogenesis in various adipose tissue in the growing domestic pig (Sus domesticus). Comp Biochem Physiol B 1995, 111:379-384.

55. Mildner AM, Clarke SD: Porcine fatty acid synthase: cloning of a complementary DNA, tissue distribution of its mRNA and suppression of expression by somatotropin and dietary Protein. J Nutri 1991, 121:900-907.

56. Kramer SA, Bergen WG, Grant AL, Merkel RA: Fatty acid profiles, lipogenesis, and lipolysis in lipid depots in finishing pigs treated with recombinant porcine somatotropin. J Anim Sci 1993, 71:2066-2072.

57. Akihiko K, Nobuko I, Hitomi F, Tamio N, Takehiko T: Influence of diet on the transcriptional and post-transcriptional regulation of malic enzyme induction in the rat liver. Eur J Biochem 1987, 168:487-491.

58. Hood RL, Allen CE: Comparative methods for the expression of enzyme data in porcine adipose tissue. Comp Biochem Physiol B 1973, 44:667-686.

59. Morris SM, Winberry LK, Fisch JE, Back DW, Goodridge AG: Developmental and nutritional regulation of the messenger RNAs for fatty acid synthase, malic enzyme and albumin in the livers of embryonic and newly-hatched chicks. Mol Cell Biochem 1984, 64:63-68.

60. Farese RV, Yost TJ, Eckel RH: Tissue-specific regulation of lipoprotein lipase activity by insulin/glucose in normal-weight humans. Metab Clin Exp 1991, 40:214-216.

61. Zechner R: The tissue-specific expression of lipoprotein lipase: implications for energy and lipoprotein metabolism. Curr Opin Lipidol 1997, 8:77-88.

62. Florence G, Pascal F, Isabelle D: ADD-1/SREBP-1 is a major determinant of tissue differential lipogenic capacity in mammalian and avian species. $J$ Lipid Res 2001, 42:106-113.

63. Benjamin W, Gellhorn A, Wagner M, Kundel H: Effect of aging on lipid composition and metabolism in the adipose tissues of the rat. Amer $J$ Physiol 1961, 210:540-546.

64. Gellhorn A, Benjamin W: Lipid biosynthesis in adipose tissue during aging and in diabetes. Ann NY Acad Sci 1965, 131:344-356.

65. McMeekan CP: Growth and development in the pig, with special reference to carcass quality characters. J Agr Sci 1940, 30:276-344.

66. Anderson DB, Kauffman RG: Cellular and enzymatic changes in porcine adipose tissue during growth. J Lipid Res 1973, 14:160-168.

67. Scott RA, Cornelius SG, Mersmann HJ: Effects of age on lipogenesis and lipolysis in lean and obese swine. J Anim Sci 1981, 52:505-511.

68. Mersmann HJ, Allen CD, Chai EY, Brown LJ, Fogg TJ: Factors influencing the lipogenic rate in swine adipose tissue. J Anim Sci 1981, 52:1298-1305.

69. Etherton TD, Chung CS: Preparation, characterization, and insulin sensitivity of isolated swine adipocytes: comparison with adipose tissue slices. J Lipid Res 1981, 22:1053-1059.

doi:10.1186/1743-7075-7-6

Cite this article as: Zhao et al:: Impact of dietary protein on lipid metabolism-related gene expression in porcine adipose tissue. Nutrition \& Metabolism 2010 7:6.

\section{Submit your next manuscript to BioMed Central and take full advantage of:}

- Convenient online submission

- Thorough peer review

- No space constraints or color figure charges

- Immediate publication on acceptance

- Inclusion in PubMed, CAS, Scopus and Google Scholar

- Research which is freely available for redistribution 